\title{
Geoheritage of Postglacial Areas in Northern Poland-Prospects for Geotourism
}

\author{
Izabela Jamorska ${ }^{1}$ (D) $\cdot$ Marcin Sobiech $^{1} \cdot$ Tomasz Karasiewicz $^{1} \cdot$ Karol Tylmann $^{2}$
}

Received: 6 December 2018 / Accepted: 7 January 2020 / Published online: 29 January 2020

(C) The Author(s) 2020

\begin{abstract}
This study aims to identify potential geosites and show existing geosites in a young glacial landscape in northern Poland through a qualitative assessment of the local geoheritage. Three areas of diversified morphology and geology located within the extent of the last Scandinavian Ice Sheet have been selected as the research polygons: the north-eastern part of the Dobrzyń Lake District, the Lower Vistula Valley and the Kashubian Lake District. Three basic abiotic components of the environment have been analysed: geology, terrain relief and hydrology. This research is based on some specific materials including maps and photographs. Methodology of this research includes the inventory, characterization and assessment of selected areas. The final results are proposals for geosites of high educational value in each of the three investigated regions. For the north-eastern part of the Dobrzyń Lake District, the creation of a geopark has been proposed, and the geosites of the Lower Vistula Valley provide the potential for a geotourist footpath to be designed. The Kashubian Lake District is characterised by the occurrence of numerous glacial landforms and sediments as well as high denivelations and a concentration of erratic boulders. Therefore, this region also has the potential to be selected for valuable geosites and the designing of a geotourist footpath.
\end{abstract}

Keywords Geoheritage $\cdot$ Glacial landscape $\cdot$ Geosites $\cdot$ Potential geopark

\section{Introduction}

Geoheritage focuses on the diversity of minerals, rocks, fossils and also includes landforms and other geomorphological features that illustrate the effects of present and past Earth's climate and physical processes (McBriar 1995). The term geoheritage (geological heritage) was used at the 1 st International Symposium on the Conservation of our Geological Heritage at Digne, France, in 1991. Between 1991 and 2006, a variety of definitions of geoheritage appeared in the literature (e.g. Bradbury 1993; Kozłowski

This article is part of the Topical Collection on Geoheritage and Conservation: Modern Approaches and Applications Towards the 2030 Agenda, IX ProGEO Symposium, Poland, 25-28th June, 2018

Izabela Jamorska

izabela.jamorska@umk.pl

1 Faculty of Earth Sciences, Nicolaus Copernicus University in Torun, Ulica Lwowska 1, 87-100 Toruń, Poland

2 Faculty of Oceanography and Geography, University of Gdańsk, Ulica Marszałka Józefa Piłsudskiego 46, 81-378 Gdynia, Poland
1999; Semeniuk and Semeniuk 2001; Grey 2004, 2005; Brocx and Semeniuk 2007, 2011; Brilha 2002, 2016, 2017). In this paper, we have used the term geoheritage after Semeniuk and Semeniuk (2001, p. 183) who defined it in the following manner: "global to national to state-wide important features of geology, including igneous, metamorphic, sedimentary, stratigraphic, structural, geochemical, mineralogic, paleontologic, pedologic and hydrologic attributes, that offer important information or insights into the formation or evolution of the Earth; or that can be used for research, teaching, or reference".

Geosites "generally represent geoheritage resources which should be studied, conserved, and developed to ensure that future generations can continue learning the geological history of the Earth" (Bruno 2015). The term geomorphosite has recently been introduced as an acronym for geomorphological site (Panizza 2001). It is understood to be a landform that has acquired a special value due to human perception or exploitation (Pereira et al. 2008). They can be single geomorphological objects or wider landscapes. The value of geomorphosites is poorly known to the public and to scientists from other disciplines (Reynard and Panizza 2005). In our contribution, we have decided to use the term 'geosites'. 
The geoheritage and potential geosites of the glacial landscapes of northern Poland presented in our study are complementary pieces of information in relation to the other studies describing the interesting features of glacial landscapes in Poland.

During the Pleistocene (Quaternary), a considerable cooling of the climate occurred, which resulted in the development of the continental ice sheets, such as the Scandinavian Ice Sheet (SIS) in Europe (Ehlers et al. 2011). Ice sheets eroded their beds and transported sediments containing a very wide spectrum of particles: from fine clay to coarse erratic boulders. Ice sheet also transformed the morphology of areas in course of the erosion, transportation and deposition of sediment. Regions located beyond the extent of inland ice were transformed by periglacial processes in a cool and dry climate involving aeolian processes (French 2007).

In Poland, seven Pleistocene continental glaciations occurred (Marks et al. 2016). The most extensive Pleistocene glaciation (the Sanian 1 Glaciation, correlated with Marine Isotope Stage 16) left sediments and landforms that were covered by subsequent glaciations or were subjected to extensive denudation during the interglacial periods. The terrain relief of central Poland was formed during younger phase of the Odranian (Saalian) Glaciation, correlating with Marine Isotope Stage 6 . That was the last period when the SIS covered the central part of Poland and, since its recession ca. $130 \mathrm{kyr}$, this region has been influenced by long-lasting periglacial processes. These processes have caused the far-reaching denudation of glacial landforms. Thus, the glacial landscape in central and southern Poland is called an 'old glacial landscape'. There is a 'young glacial landscape' in northern Poland, and it covers approximately $30 \%$ of the country. The young glacial area was affected by the last Pleistocene continental glaciation, referred to in Poland as the Vistulian (Weichselian) Glaciation and correlated with Marine Isotope Stages 5d-2 (Marks et al. 2016). The maximum extent of the SIS during the Weichselian Glaciation occurred in Marine Isotope Stage 2 during the Leszno Phase (ca. $2521 \mathrm{kyr}$ ) in western Poland and during the Poznań Phase (ca. 22-18 kyr) in eastern Poland (Wysota et al. 2009; Marks 2012; Tylmann et al. 2019). After this time, the last SIS started to retreat progressively releasing fresh glacial landforms. The general retreat of the ice front was interrupted by a local glacial re-advances and an ice margin standstills. In the Kujawy-Dobrzyń region the local ice readvance occurred during the Kujawy-Dobrzyń Subphase which is correlated with Chodziez Subphase dated at ca. 17.7 kyr (Kozarski 1995; Wysota et al. 2002). Later, the significant ice margin standstill occurred across the Pomerania region during the Pomorska Phase dated at ca. 17-16 kyr (Marks 2012). The last ice sheet re-advance into the territory of Poland occurred in northernmost Poland during the Gardno Phase around 14.0-13.8 kyr (Mojski 2005). After the final deglaciation of the northern Poland but before the start of Holocene ca. $11.7 \mathrm{kyr}$, the period called Late Glacial occurred (between ca. 13.8 and ca. $11.7 \mathrm{kyr}$ ). This is the end of Pleistocene, when the ice sheet did not occupy territory of Poland anymore and because of climatic fluctuations, it is divided to minor climatic phases such as: the Oldest Dryas, Bølling/Allerød and Younger Dryas.

The relief of the young glacial landscape of northern Poland is variegated and consists of various glacial landforms. The Pleistocene sediments reach the maximum thickness of over 200-300 m. They consist of glacial tills, glaciofluvial sands and gravels, glaciolacustrine silts and clays as well as erratic boulders and glacial drifts of older deposits (e.g. Paleogene or Neogene sediments). Glacial and glaciofluvial deposits are occasionally separated by interglacial sediments, such as fluvial sands, lacustrine silts and clays or peats, which indicate warmer periods of the Pleistocene.

Most of the young glacial landscape is covered with till and glaciofluvial sands and gravels, which form moraines or moraine plateaux, and outwash plains or fans, respectively. These landforms are frequently intersected by river valleys and tunnel valleys. The whole picture of the postglacial landforms is complemented by a series of terminal moraines and depressions, kames, kame terraces, drumlins, eskers, dead-ice moraines, kettle holes and marginal valleys, including marginal spillways.

The authors of this paper have decided to analyse selected areas in northern Poland in more detail. The aim of our contribution is to recognise and present the geoheritage of the young glacial landscape in northern Poland. For each of the three studied regions, the authors have taken advantage of the previously described geosites at the website of geosite database of the Polish Geological Institute-National Research Institute (abbreviation: PGI-NRI), http//geostanowiska.pig.gov.pl, and have proposed some new potential geosites. Hitherto, the areas of glacial landscape studied by us have not been evaluated in terms of geological heritage. In the Polish literature, the evaluation of geodiversity and geological heritage is usually used for highland and mountainous regions of southern Poland (e.g. Alexandrowicz 2006, 2008; Alexandrowicz et al. 1998, 2019; Migoń and Pijet-Migoń 2016; Miśkiewicz et al. 2008; Zgłobicki and BaranZgłobicka 2013; Zwoliński 2010; Urban and Gagol 2008). The northern part of Poland has still not often been investigated in this regard.

The geodiversity index of the abiotic environment in the Chełmno Lake District was studied by Kot (2012). This author, while investigating the 'Fordon sector' of the Vistula River Valley, analysed the problem of searching the right methods for the evaluation of geodiversity in lowland areas (Kot 2006). The recession of the last SIS and development of ice-marginal spillways were analysed in a study by RatajczakSzczerba (2011). This study presents the geomorphological characteristics of the terrain along the middle Noteć River Valley and it shows the geological diversity, the spectrum of 
landforms, and the mosaic of lakes, peatbogs and forests there. An extensive and complex evaluation of geodiversity was also conducted in the glacial areas of western Poland: Drawieński National Park with a young glacial landscape, and the UNESCO Global Muskau Arch Geopark with an old glacial landscape. Górska-Zabielska et al. (2015) assessed the geodiversity, geoheritage and geotourist attractiveness of the Drawieński National Park with an evaluation on two levels: valorisation of the areas and of the objects. Additionally, this study was supplemented with analyses of cartographic materials and literary data, and valuable geosites in terms of science and tourism were proposed. In the case of the Muskau Arch Geopark, besides studies related to its geodiversity, we may find studies related to the foundation of the Geopark and the destination of geotourist footpaths (Badura et al. 2003; Świerkosz et al. 2017). Some information about postglacial area we can find in articles about the potential Yotvings Geopark (Graniczny et al. 2008) located at the border of Poland and Lithuania, and in the article Nizicka et al. (2008), were the authors described geotourism in the Suwałki Landscape Park.

The analyses we conducted have allowed us to propose potential new geosites with the features of the 'old glacial' landscape (Górzno area), and with the features of the 'young glacial' landscape (Górzno area, Lower Vistula Valley and Kashubian Lake District). Furthermore, we have presented examples of the landforms typical of large river valleys, morainic areas and regions of transition from the old glacial landscape to the young glacial landscape.

\section{Study Area}

The study area consists of three regions of northern Poland: the north-eastern part of the Dobrzyń Lake District near a small town, Górzno (hereinafter referred to as the Górzno area), the Lower Vistula Valley and the Kashubian Lake District (Fig. 1).

Both the Kashubian and the Górzno areas represent typical young glacial landscapes, while the Lower Vistula Valley is a 6 - to $8-\mathrm{km}$-wide valley with old and complex origin. The parameters significant to the proper evaluation of the research areas have been summarised in Table 1.

The Górzno area borders the young (Vistulian) and the old glacial (pre-Vistulian) landscapes, and this border is morphologically pronounced as the NE-SW Weichselian ice-marginal belts. These latter were formed during the Poznań Phase and the younger Kujawy-Dobrzyń Subphase of the maximum extent of the last Scandinavian Ice Sheet (SIS). The ice-marginal zone of the Kujawy-Dobrzyń Suphase is vivid and well expressed by occurrence of numerous moraine landforms, glacial tunnel valleys and moraine plateaus, along with few levels of the outwash plains. Combine abovementioned, the Górzno area serves as a nature conservation of numerous forms as three landscape parks, eight nature reserves, six protected landscape areas, seven Nature 2000 areas and over five hundred natural monuments, three of which are glacial erratic boulders.

The Lower Vistula Valley is a ca. 110-km-long northern segment of the Vistula River Valley. The Lower Vistula Valley is oriented SSW-NNE; its width varies from approximately $2.3 \mathrm{~km}$ in the south to $19 \mathrm{~km}$ in the central part of the studied area. The Pleistocene ice sheets eroded the valley within the Miocene deposits. The initial form of the Valley was probably re-eroded many times during the Pleistocene (Mojski 2005; Weckwerth 2018). The Lower Vistula Valley was finally formed as a result of the last ice sheet recession followed by the water flowing to the north and the fluvial erosion in the Allerød Phase ca. 13.9-12.9 kyr (Weckwerth $2006,2010)$. Today, the valley is a wide landform incised 50 $60 \mathrm{~m}$ below the surface of the surrounding moraine plateau. The sides of the valley are mostly steep escarpments with numerous small erosional-denudational valleys formed during the Late Glacial and Holocene. There exist in the valley glaciofluvial and fluvial terraces as well as typical fluvial landforms connected with recent river activity such as bars, levees and floodplains or oxbow lakes. On the surface of the terraces as well as at the bottom of the valley, there occur sand dunes as a result of the Late Glacial and Holocene aeolian processes. The sediments within the valley are mainly glaciofluvial and fluvial sand and gravel, mud, peat and aeolian sand (Table 1).

The Kashubian Lake District is located in the northern Poland, and it has the largest area (over $3500 \mathrm{~km}^{2}$ ) of the three studied regions (Table 1). It is an elevated morainic terrain containing the highest hill of the Polish postglacial landscape-Wieżyca (328.7 m a.s.1.). In the Kashubian Lake District, over 500 lakes are situated, and the lake index is ca. $3.5 \%$. The majority of lakes are of glacial origin, with a predominance of tunnel channel lakes. The biggest lake in this region is Raduńskie Dolne Lake. The topography of the Kashubian Lake District is diversified: the elevation of the terrain varies from $0 \mathrm{~m}$ a.s.l. at the eastern edge of the studied area up to almost $329 \mathrm{~m}$ a.s.1. in the south-central part (Table 1). The local differences in height often exceed $50 \mathrm{~m}$ and, in the vicinity of Wieżyca Hill, reach up to ca. $160 \mathrm{~m}$. Very distinct and fresh postglacial landforms (mainly moraines, moraine plateaux and tunnel channels) make the topography diverse. One of the most characteristic features of the Kashubian postglacial landscape is a dense network of conspicuous tunnel valleys which are incised down to $50 \mathrm{~m}$ into the surface of moraine plateau. Most of the tunnel valleys are oriented NE-SW, and were finally formed as a result of the subglacial meltwater erosion of the ice sheet bed during the Pomorska Phase. The surface sediments that prevail in this region are glacial tills, glaciofluvial sands and gravels and end moraine deposits (Table 1). The thickness of the Quaternary deposits varies between ten to over $300 \mathrm{~m}$. 
Fig. 1 Location of the research areas

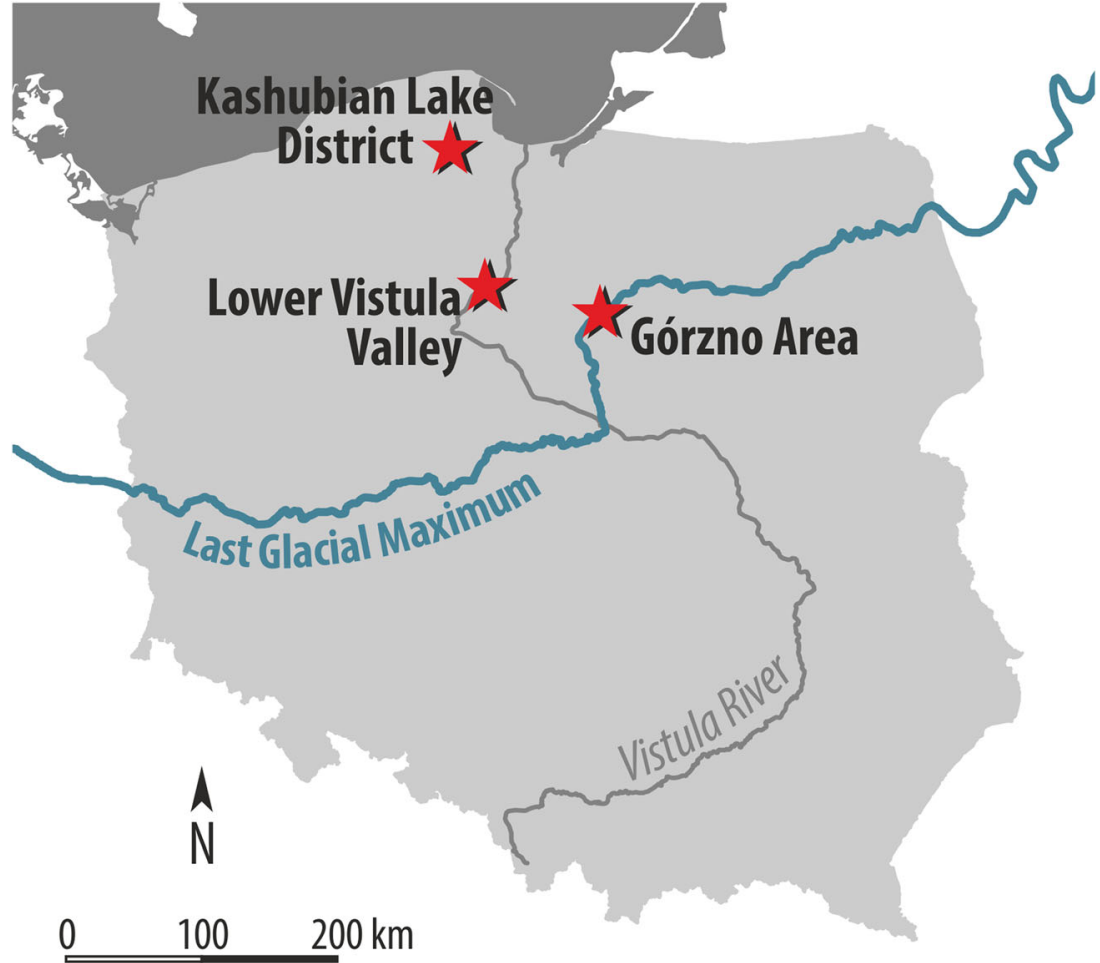

\section{Methods}

In order to display the geoheritage of selected postglacial areas in Poland, research has been conducted based on cartographic materials, scientific publications, GIS analyses and field studies. Surface geology has been compiled based on the Gdańsk, Słupsk, Grudziądz, Torun and Brodnica sheets of the 1:200,000 Geological Map of Poland. In order to propose attractive geosites, 1:100,000 geomorphological maps and the geosite database of the Polish Geological InstituteNational Research Institute (www.geostanowiska.pig.gov.pl) have been used. The hydrographic data have been collected based on a raster map of the Hydrographic Divisions of Poland (http://mapa.kzgw.gov.pl/). The data have been compiled in GIS and maps have been created showing geosites and potential geosites characterised by a high level of attractiveness for geotourism. A tabular compilation of the selected geosites and new potential geosites allows the analysed postglacial areas to be compared and locations to be proposed for new potential geoparks and geotourist footpaths.

\section{Results}

\section{The Górzno Area}

The Górzno area (Fig. 2) represents a transition between an old and a young glacial landscape with a large inventory of glacial landforms. The diversification of the landscape is high and the dynamics of the topography is significant. Except of the two geosites which can be found in the database of geosites (www.geostanowiska.pig.gov.pl), we propose seventy seven potential new geosites arranged in seventeen geomorphological categories, the majority of which are glacial landforms and the rest are fluvial landforms (Table 2). The glacial landforms document the transgressions, standstills and recessions of the older Saalian and the younger Weichselian glaciations (MIS 5d-2; the maximum extent of the last ice sheet and the Kujawy-Dobrzyń Subphase; see Wysota 1992; Niewiarowski et al. 1995; Kotarbiński 1996, 1998; Sobiech and Wysota 2014; Sobiech 2012 unpublished master's thesis).

The old glacial landforms of the Górzno area are located near the Wkra River Valley (Fig. 2) where the Saalian (MIS 6) moraine plateau and terminal moraines occur. These Saalian terminal moraines are herein proposed as potential new geosite no. 1 (Table 2). Most of the Saalian moraine plateau is covered with younger outwash sediments and only its highest fragments rise above the cover of glaciofluvial sediments as characteristic remnants of the moraine plateau. These remnants form hillock-like structures, which are proposed as a potential geosite no. 2 (Table 2). The maximum extent of the Weichselian Glaciation in the area east of Górzno City is delimited by the ice-contact sedimentary scarp within the outwash plain (Fig. 2). The line of the maximum extent of the ice sheet is oriented NE-SW here, and the sedimentary scarp has been selected as a geosite and potential geosite no. 3 
Table 1 Characteristics of the selected research areas

\begin{tabular}{|c|c|c|c|c|}
\hline Parameter & Unit & The Górzno Area & The Lower Vistula Valley & The Kashubian Lake District \\
\hline \multicolumn{5}{|l|}{ Geomorphometric parameter } \\
\hline Area & $\mathrm{km}^{2}$ & 1002.5 & 1172.5 & 3522.5 \\
\hline \multicolumn{5}{|l|}{ Topographical characteristics } \\
\hline Maximum height & m a.s. 1. & 190 & 106 & 320 \\
\hline Minimum height & m a.s. 1. & 70 & 7 & 0 \\
\hline Average height & m a.s. 1. & 137 & 35 & 153 \\
\hline Median & m a.s. 1. & 158 & 25 & 140 \\
\hline \multicolumn{5}{|l|}{ Hydrographical characteristics } \\
\hline Main watercourses in the area & $(-)$ & Drwęca, Skrwa & Vistula & Radunia, Wierzyca \\
\hline Largest lakes in the area (ha) & $(-)$ & Lidzbarskie (123) & Rudnickie Wielkie (149) & Raduńskie Dolne (716.5) \\
\hline \multicolumn{5}{|l|}{ Environmental characteristics } \\
\hline $\begin{array}{l}\text { Geology — dominating } \\
\text { surface deposits }\end{array}$ & $(-)$ & $\begin{array}{l}\text { Glacial tills (Weichselian), } \\
\text { glaciofluvial sands and } \\
\text { gravels, glacial tills } \\
\text { (Late Saalian) }\end{array}$ & $\begin{array}{l}\text { Sands, gravels, fluvial muds, } \\
\text { peats and silts, glacial tills } \\
\text { and glaciofluvial gravels, } \\
\text { glaciofluvial sands and } \\
\text { gravels, aeolian sands }\end{array}$ & $\begin{array}{l}\text { Glacial till, glaciofluvial } \\
\text { sands and gravels, terminal } \\
\text { moraine sands, gravels and } \\
\text { clays }\end{array}$ \\
\hline Geomorphology & $(-)$ & $\begin{array}{l}\text { Moraine upland, outwash } \\
\text { plains, old glacial moraine } \\
\text { upland }\end{array}$ & $\begin{array}{l}\text { River valley, moraine upland, } \\
\text { outwash plain, aeolian dunes }\end{array}$ & $\begin{array}{l}\text { Moraine upland, marginal } \\
\text { forms }\end{array}$ \\
\hline Vegetation cover & $(-)$ & $\begin{array}{l}\text { Arable land, coniferous forests, } \\
\text { meadows and pastures }\end{array}$ & $\begin{array}{l}\text { Arable land, coniferous forests, } \\
\text { meadows and pastures }\end{array}$ & $\begin{array}{l}\text { Arable land, coniferous and } \\
\text { mixed forests, agricultural } \\
\text { areas with sizeable natural } \\
\text { vegetation }\end{array}$ \\
\hline
\end{tabular}

(Table 2). On the surface of the higher outwash level, numerous sedimentary forms pointing to the diversified dynamics of meltwater outflow occur, e.g. systems of distributive channels in the proximal part of the outwash fan. The latter ones which have been selected as a potential geosite no. 4 (Table 2).

During the recession of the Weichselian ice sheet, after its maximum extent had been reached, a significant ice front standstill occurred during the Kujawy-Dobrzyń Subphase (Fig. 2). Subglacial waters formed over a dozen tunnel valleys (Fig. 3a) and a few eskers. They have been selected as potential geosite nos. 5 and 6, respectively (Fig. 2). The morphological axis of the ice-marginal belt of the Kujawy-Dobrzyń Subphase consists of mainly glacial depressions, terminal moraines, relicts of ice-cored moraines and push moraines. We have chosen these unique examples of ice-marginal landforms as potential geosites no. 7 (glacial depression), 8 (terminal moraines), 9 (relict ice-core moraines) and 10 (push moraines) (Table 2). In the hinterland of the palaeo-ice margin correlated with the Kujawy-Dobrzyń Subphase, systems of glacial curvilineations (GCL) have been found. These are enigmatic subglacial bedforms previously interpreted as drumlins (Wysota 1992), but recently explained as erosional remnants of channelized subglacial meltwater flow (e.g. Lesemann et al. 2010, 2014; Karasiewicz et al. 2014). We have proposed these interesting landforms, which are easily traceable in the landscape, as a potential geosite no. 11 (Table 2).
Kames and kame terraces represent a large group of glaciolimnic landforms in the study area, related to an areal style of deglaciation, which is a collapse of the ice sheet into isolated dead-ice blocks. The highest concentration of these landforms occurs in the central part of the research area and to the north and north-west of Górzno. We have proposed an example of kames and kame terraces as a potential geosite no. 12 (Table 2). The degradation of the dead-ice blocks after deglaciation caused the formation of kettle holes. The occurrence of several thousand kettle holes has been reported in the analysed region, especially on the surface of the outwash plains. We have selected a representative kettle hole area as a potential geosite no. 13. In the Górzno area, the glacial landscape is dominated by a flat and hummocky moraine plateau. The hummocky moraine plateau, which is an interesting example of a wavy landscape, has been selected as a potential geosite no. 14 (Table 2).

Besides the dominating glacial features, some interesting fluvial landforms also occur in the Górzno area. The formation of the river network occurred after the final recession of the Weichselian ice sheet, the melting of the buried dead-ice blocks and the degradation of the permafrost. Some interesting evidence of the river network's evolution is the occurrence of river valleys, spring niches and river deltas. We have chosen representative spring niche, river valleys (Fig. 3b) and two river deltas as potential geosite nos. 15, 16 and 17, respectively (Table 2 and Fig. 2). 
Fig. 2 Geological map of the Górzno area with the location of the geosites (black circles) and potential geosites (red circles). $\mathrm{R}$, river

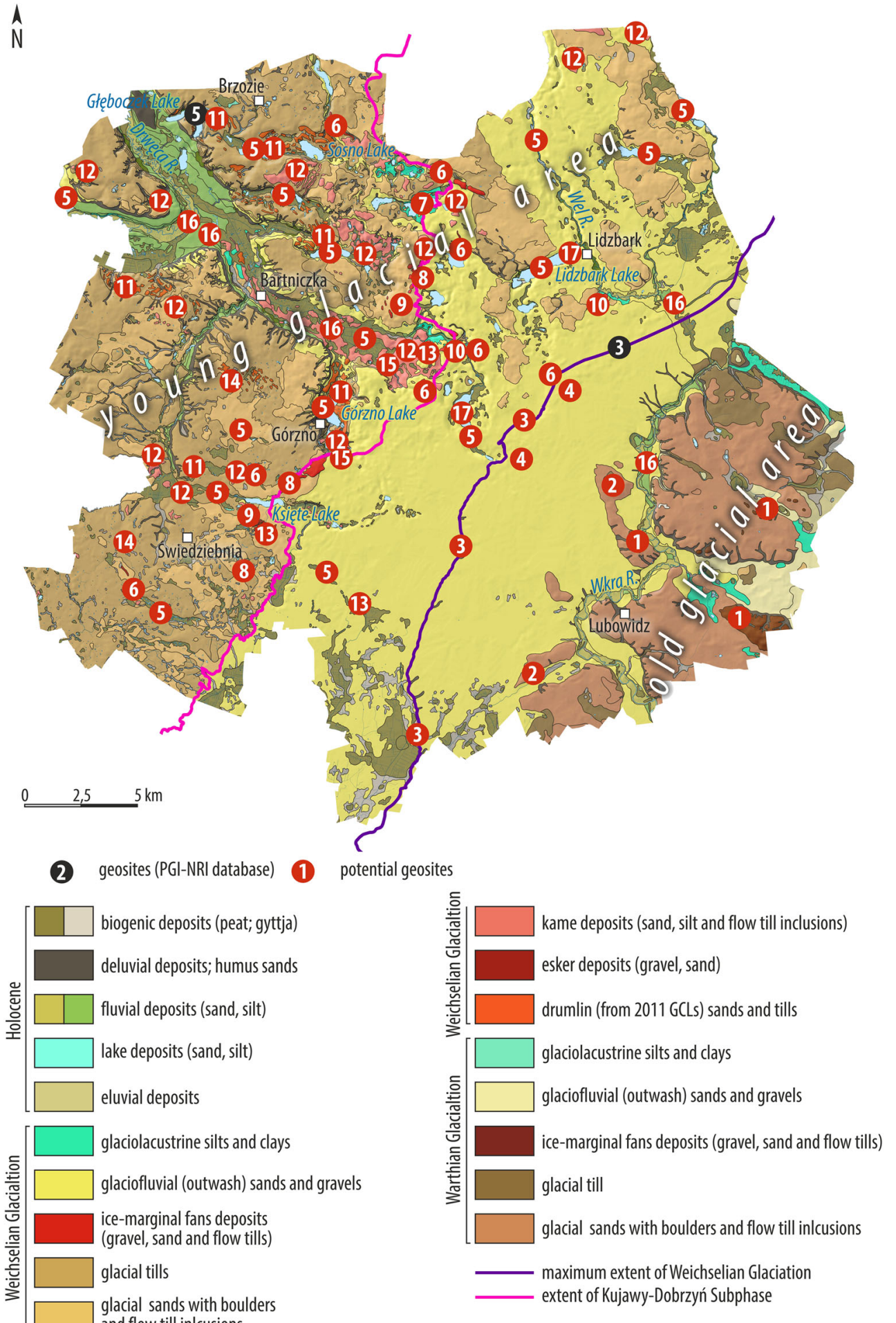

\section{The Lower Vistula Valley}

The geosites selected in the Lower Vistula Valley (Fig. 4) can be grouped into five geomorphological categories: (1) landforms and sediments, (2) caves, (3) spring fens, (4) lakes and (5) landslides (Table 3).
The landforms and sediments selected as attractive and highly educational represent glacial, fluvial and aeolian features. In the southern part of the analysed segment of the Lower Vistula Valley, the Vistula River turns sharply from NNW to NE (Fig. 4). In this place, the river breakthrough called the 'breakthrough near Fordon' was formed at the end 
Table 2 Examples of geosites and potential geosites in the Górzno area. Numbers refer to geosites presented in Fig. 2

\begin{tabular}{llll}
\hline No. & Geosites and potential geosites & No. & Geosites and potential geosites \\
\hline 1 & Old terminal moraines (Saalian) & 10 & Push moraines \\
2 & Remnants of old moraine plateau (Saalian) & 11 & Glacial curvilineations (GCL) \\
3 & Ice-contact sedimentary scarp (Weichselian) & 12 & Kames and kame terraces \\
4 & Outwash fans (with distributed channels) & 13 & Kettle holes \\
5 & Subglacial tunnel valleys & 14 & Hummocky moraine \\
6 & Eskers & 15 & Spring niche \\
7 & Glacial depressions & 16 & River valleys \\
8 & Terminal moraines & 17 & River deltas \\
9 & Relicts of ice-cored moraines & & \\
\hline
\end{tabular}

of the Weichselian Glaciation (Weckwerth 2006, 2010). The best viewpoint for this breakthrough is located on the Vistula escarpment near Jarużyn. The river valley there is only $2.5 \mathrm{~km}$ wide and has been selected as a geosite no. 1 (Table 3). Erosional incisions of various shapes and dimensions are located on the slopes of the Lower Vistula Valley. They were formed by meltwaters and rainwaters flowing from the moraine plateau towards the valley bottom. We may observe gorges of considerable sizes. Some examples are a 900-mlong ravine located in Gadecz or the 4-km-long and up to 50-m-deep Cieleszyński Ravine (Urban 2000, 2007, 2015). These very conspicuous landforms were selected as a geosite no. 2. At the outlets of the gorges and ravines, alluvial fans often occur. An example may be the extensive alluvial fans near Gruczno, which have been selected as a geosite no. 3 (Table 3). The Fletnowo tunnel valley is $10 \mathrm{~km}$ long, $150 \mathrm{~m}$ wide and ca. $20 \mathrm{~m}$ deep (Roszko 1968). It occurs at the bottom of the Lower Vistula Valley and it was formed as a result of the subglacial meltwater erosion of the ice sheet bed during the last glaciation. In 1995, a nature reserve was created here to protect a unique geomorphological feature: a glacial tunnel channel with a lake cross cutting longitudinally through the Grudziądz Basin. This glacial landform has been selected as a geosite no. 4. An interesting element of the glacial and fluvial landscape in the analysed area is the remnants of morainic erosion-hillocks near Grudziądz. They have been selected as geosite no. 5 (Fig. 4). Moreover, aeolian forms also occur in this area. Numerous dunes are located at the bottom of the Lower Vistula Valley and on the surface of the moraine plateau. They were selected as geosite nos. 6 and 7, respectively (Table 3). The Lower Vistula Valley region is the perfect place to search for natural exposures of Quaternary deposits. In Gruczno, an interesting exposure of the Weichselian glacial till occurs (Fig. 4). In addition, an exposure of thick Weichselian deposits may be observed in Morsk. This is one of the few exposures in Poland with such diversified (genetically and lithologically) Weichselian deposits (Olszewski 1976). These exposures have been selected as potential geosites nos. 8 and 9 (Table 4). The Vistula River is incised deeply into the moraine plateau, so a very high escarpment of the valley may be observed in Zakurzewo, where geosite no. 10 is proposed. In the analysed segment of the Lower Vistula Valley, there are several tributaries of the Vistula River. Some of them have their own interesting valleys (e.g. the Wda or Osa rivers) which also have been be selected as potential geosites (no. 11).

Because of the deep incision of the Vistula River within the surrounding moraine plateau, numerous spring fens and spring niches are located on the steep slopes of the moraine plateau. These examples of geomorphological and hydrographical features have been selected as geosites nos. 12 and 13 (Table 3). The existence of the spring fens is related to the movement of groundwaters along the moraine plateau towards the Lower Vistula Valley. As a result of the movement of groundwater through the Weichselian glacial till and the leaching of calcium carbonate, sand and gravel lying below the till layers were transformed into Pleistocene conglomerates due to cementation with $\mathrm{CaCO}_{3}$. In the upper part of the Cieleszyński Ravine, three natural exposures of Pleistocene conglomerates and sandstones are located (Urban 2015). The biggest exposure is $15 \mathrm{~m}$ long and $3 \mathrm{~m}$ high. These exposures have been selected as a potential geosite no. 14 . Weathering and erosion of the conglomerates resulted in the occurrence of small caves. In the cave 'Bajka II' (Fig. 3c), located in the upper part of the ravine near Gadecz, calcite dripstones, such as a stalactite and a calcite dome, have been observed (Baryła et al. 1998; Urban 2000, 2015). The caves have been selected as a geosite no. 15 (Table 3).

Two kettle hole lakes of glacial origin have been preserved in the Grudziądz Basin, i.e. Rudnik and Tarpno Lakes. They have been selected as a potential geosite no. 16. At present, in the area of the Lower Vistula Valley, the Vistula river channel is regulated, but until the regulatory works in the nineteenth century, Vistula was a braided or meandering river. Remnants of the meandering process are oxbow lakes (Fig. 3d), which have been selected as a potential geosite no. 17. Finally, the high slopes of the Vistula valley and the occurrence of clay sediments within the slopes facilitate mass movements (Tyszkowski 2015). Thus, in many places, active or fossil landslides can be observed. We have chosen the most 
Fig. 3 Photos of the selected geosites.. a Subglacial tunnel valley and Górzno Lake. b Brynica River Ravine. c Bajka caves I and II. d Starogardzkie oxbow Lake. e Broken Stone erratic boulder. f Kings Stone. Photographs by Andrzej Grzywacz (a, b) Tomasz Karasiewicz (c, d) and Karol Tylmann (e, f)
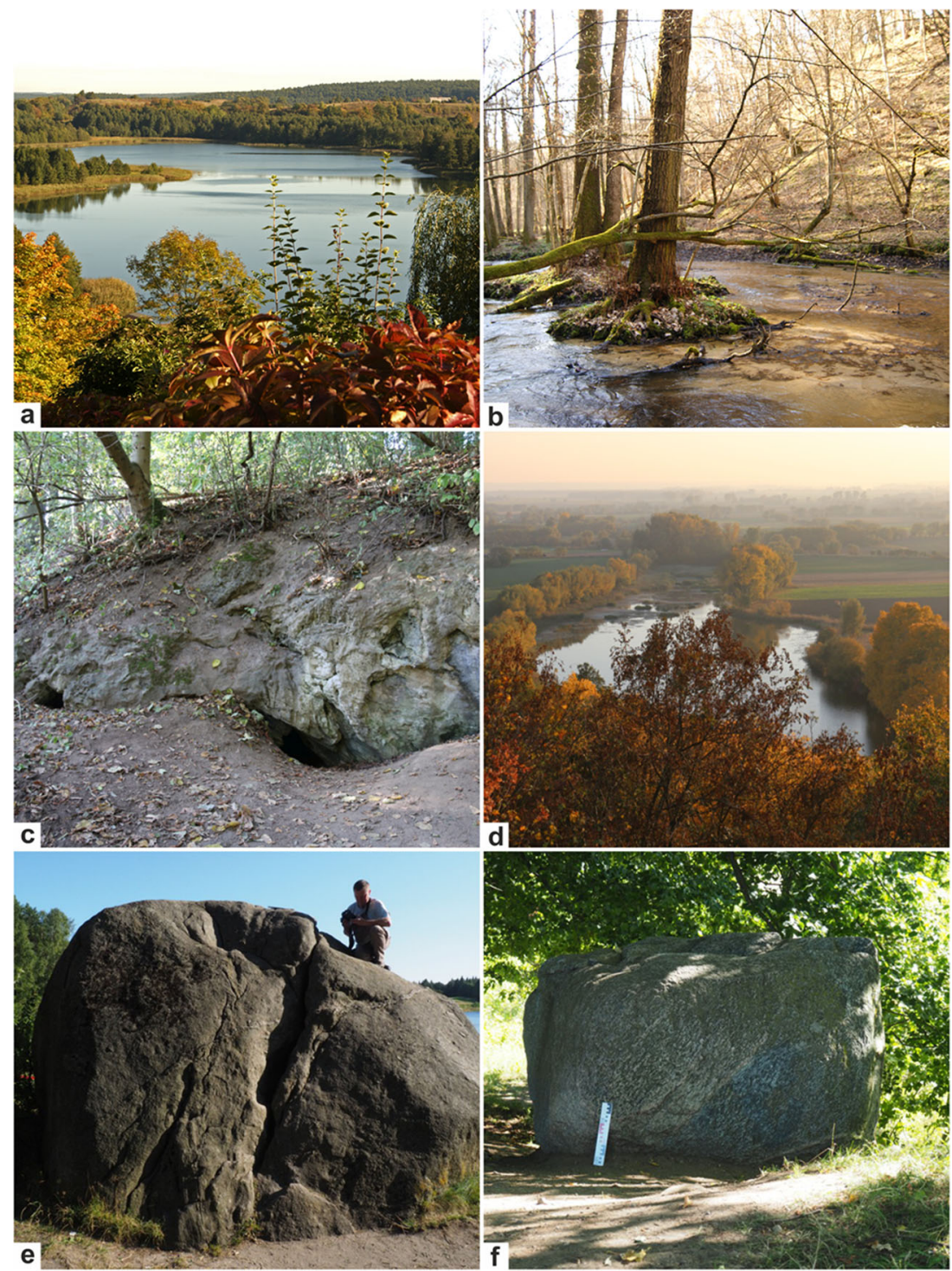

spectacular landslides as new potential geosites-no. 18 (Fig. 4), which is sizable and therefore perfectly visible in this terrain.

\section{The Kashubian Lake District}

The geosites selected in the Kashubian Lake District may be grouped into five categories: (1) landforms, (2) erratics, (3) caves, (4) peatbogs and (5) spring fens. We have chosen fourteen geosites and potential geosites; within this number, eight geosites are examples of glacial or fluvial landforms; two geosites are large erratics, other ones are peatbogs, and six are caves and spring fens.

The selected landforms are of glacial and fluvial origin. The Kashubian Lake District features the highest point of the Polish Lowlands (Wieżyca Hill, 328.7 m a.s.l.). This landform is easily recognisable in the landscape. The hill is located high above the surrounding area, and there is a fantastic viewpoint from which to see the fresh glacial landscape dominated by tunnel channel lakes and moraines. Its origin has been interpreted as end moraine correlated with the ice sheet recession during the Pomorska Phase of the Weichselian Glaciation (e.g. Roszko 1968), but recently, some researchers have interpreted the hill as a crevasse landform (Petelski and Moczulska 2006). The Wieżyca Hill has been selected as a geosite no. 1 (Table 4). Another hill, which has been selected as a geosite no. 2, is Donas Hill near Gdynia (Fig. 5). It is an end moraine correlated with the ice margin standstill during its recession in the Pomorska Phase of the last glaciation. Another great example of a glacigenic landform is an esker near the village of Głazica. This esker has been selected as a geosite no. 3 (Table 4). It is possible to observe the landform and its inner structure due to a gravel pit located within the esker. This landform is composed of sandy and gravelly 
Fig. 4 Geological map of the Lower Vistula Valley with the location of geosites (black circles) and potential geosites (red circles)
2 geosites (PGI-NRI database)

(1) potential geosites
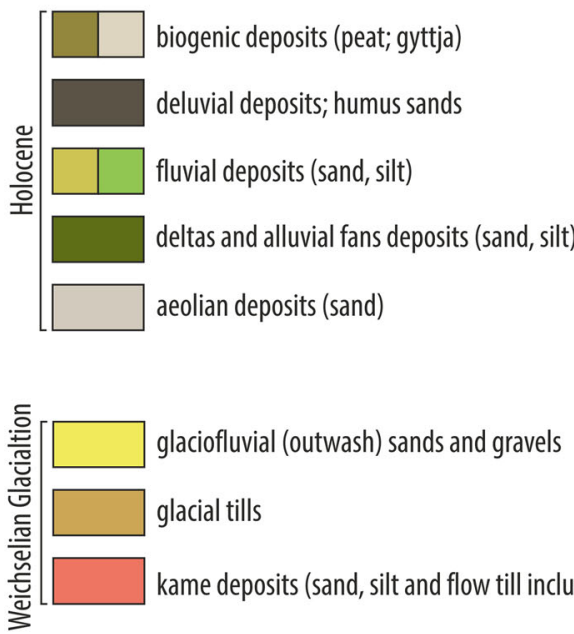

glaciofluvial (outwash) sands and gravels

glacial tills

kame deposits (sand, silt and flow till inclusions)

extent of Pomorska Phase

(Weichselian Glaciation)

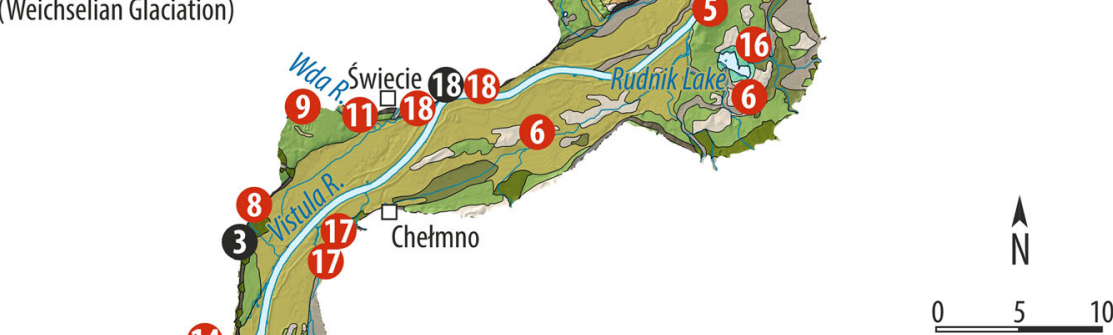

Table 3 Examples of geosites and potential geosites in the Lower Vistula Valley. Numbers refer to geosites presented in Fig. 4

\begin{tabular}{|c|c|c|c|}
\hline No. & Geosites and potential geosites & No. & Geosites and potential geosites \\
\hline 1 & The Vistula breakthrough near Fordon & 10 & High escarpment in Zakurzewo \\
\hline 2 & Gądecz and Cieleszyński ravines & 11 & River valleys (the Wda and Osa) \\
\hline 3 & Alluvial fans & 12 & Spring niches \\
\hline 4 & Fletnowo tunnel valley & 13 & Spring fens at the slope zone \\
\hline 5 & $\begin{array}{l}\text { Morainic erosional remnants—hillocks (Grupy } \\
\text { Górnej, Forteczna, Strzemięcińska) }\end{array}$ & 14 & Pleistocene conglomerates with niche \\
\hline 6 & Dunes at the bottom of the Vistula Valley & 15 & Bajka caves I and II \\
\hline 7 & Dunes at the moraine plateau & 16 & Kettle hole lakes (Rudnik and Tarpno lakes) \\
\hline 8 & Moraine plateau, exposure of glacial till & 17 & Oxbow lakes \\
\hline 9 & $\begin{array}{l}\text { Weichselian glacial and glaciofluvial sediments } \\
\text { within the escarpment of the Vistula valley }\end{array}$ & 18 & Landslides \\
\hline
\end{tabular}


Table 4 Examples of geosites in the Kashubian Lake District. Numbers refer to geosites presented in Fig. 5

\begin{tabular}{llll}
\hline No. & Geosite & No. & Geosite \\
\hline 1 & Wieżyca Hill & 8 & 'Lechicka Fissure' glacial channel \\
2 & Donas Hill & 9 & 'Broken Stone' erratic boulder \\
3 & Esker in Głazica & 10 & 'King's Stone' erratic boulder \\
4 & Zagórska Struga valley & 11 & Mirachowo caves \\
5 & Mirachowska Stream valley & 12 & Staniszewo peatbog \\
6 & Radunia Ravine & 13 & Stążki peatbog \\
7 & Raduńskie lakes tunnel valley & 14 & Staniszewo spring fen \\
\hline
\end{tabular}

deposits representing deposition within the subglacial channel below the ice sheet.

Valley landforms may be represented by Zagórska Struga Valley in the north-east of the analysed region and the Mirachowska Struga Valley in the north (Fig. 5). Both valleys are narrow and form deep incisions between morainic landforms of a typical young glacial landscape. They are very picturesque and have been selected as geosites nos. 4 and 5. In addition, one river breakthrough has been selected as a geosite no. 6-Radunia Ravine (Table 4). This ravine is also very picturesque, and it resembles more a mountainous landscape, rather than a lowland one. However, the most typical landforms for the Kashubian Lake District are glacial channels. We have selected two tunnel channels as geosite nos. 7 and 8 (Table 4). The tunnel channel of Raduńskie lakes is one of the largest glacial channels in this region. Two lakes are located within this channel: Raduńskie Dolne Lake and Raduńskie Górne Lake. The tunnel channel 'Lechicka Fissure' is a very narrow and deep glacial channel that is clearly visible in the landscape. Both tunnel channels of Raduńskie Dolne and Raduńskie Górne lakes and the Lechicka Fissure are representative examples of the most characteristic landforms of the Kashubian Lake District. Moreover, the access to these potential geosites is relatively easy.

Further examples of the glacial features characteristic for the analysed region are large erratic boulders. These pieces of Scandinavian rocks left are located in many places of the Kashubian Lake District. High concentrations of large erratic boulders are typical of areas within the extent of the ice sheet during the Pomorska Phase of the Weichselian Glaciation in northern Poland (Tylmann et al. 2018). Two large erratics have been selected as geosite nos. 9 and 10 (Table 4). The 'Broken Stone' (Fig. 3e) is a granite gneiss with a perimeter of $17.6 \mathrm{~m}$ and a height of $3.1 \mathrm{~m}$. It is located on a small lake within a glacial depression. The second boulder 'King's Stone' (Fig. 3f) is a gneiss with a perimeter of $6.1 \mathrm{~m}$ and a height of $1.5 \mathrm{~m}$. Its size is not so spectacular, but it is located at the top of a morainic hill with beautiful views over the glacial landscape of the central part of the Kashubian Lake District (Fig. 5).

In the eastern part of the glacial channel of the Lechicka Fissure, on steep slopes, outcrops of Pleistocene conglomerates and sandstones occur. Gravel and sand are cemented there with $\mathrm{CaCO}_{3}$, so karst processes and forms may be observed there. One of the most characteristic landforms and sediments of depressions of glacial origin such as kettle holes or glacial channels are peatbogs. Two peatbogs have been selected as geosite nos. 12 and 13 (Table 4). The Staniszewski and Strążki peatbogs are typical examples of so-called 'Baltic peatbogs' with a few metres of peat accumulated on the glacigenic deposits. The history of peat accumulation and associated climate changes during late Pleistocene and Holocene is well known there from palynological studies conducted on both peatbogs (Herbichowa 1998). The Staniszewo spring fen (geosite no. 14) is an area with a few springs located on the slopes of the glacial channel. The springs are located at the base of the slope and are characterised by exceptionally high outflow.

\section{Conclusions}

This study provides the 110 new potential geosites. Additionally, 23 geosites, a part of the Polish Geological Institute-National Research Institute database, are considered. The database of the Polish Geological Institute-National Research Institute (www.geostanowiska.pig.gov.pl) representing around 20 geomorphological categories that were defined taking into consideration the present geological and geomorphological knowledge about the studied areas. Some of the geosites are well documented and possess preliminary scientific, tourist as well as educational valorisation, which has been prepared by a number of authors participating in the project conducted by the PGINRI. The project was carried out on request of the Ministry of the Environment and financed by the National Fund for Environment Protection and Water Management.

The geoheritage of the Lower Vistula River Valley has been presented on the basis of thirty two new potential geosites and eight existing geosites; a detailed description of which can be found in the geosite database of the PGI-NRI. According to this database, 125 of the existing geosites situated within the boundaries of the Kashubian Lake District have been described, the majority of which are erratic 
Fig. 5 Geological map of the Kashubian Lake District with the location of the geosites
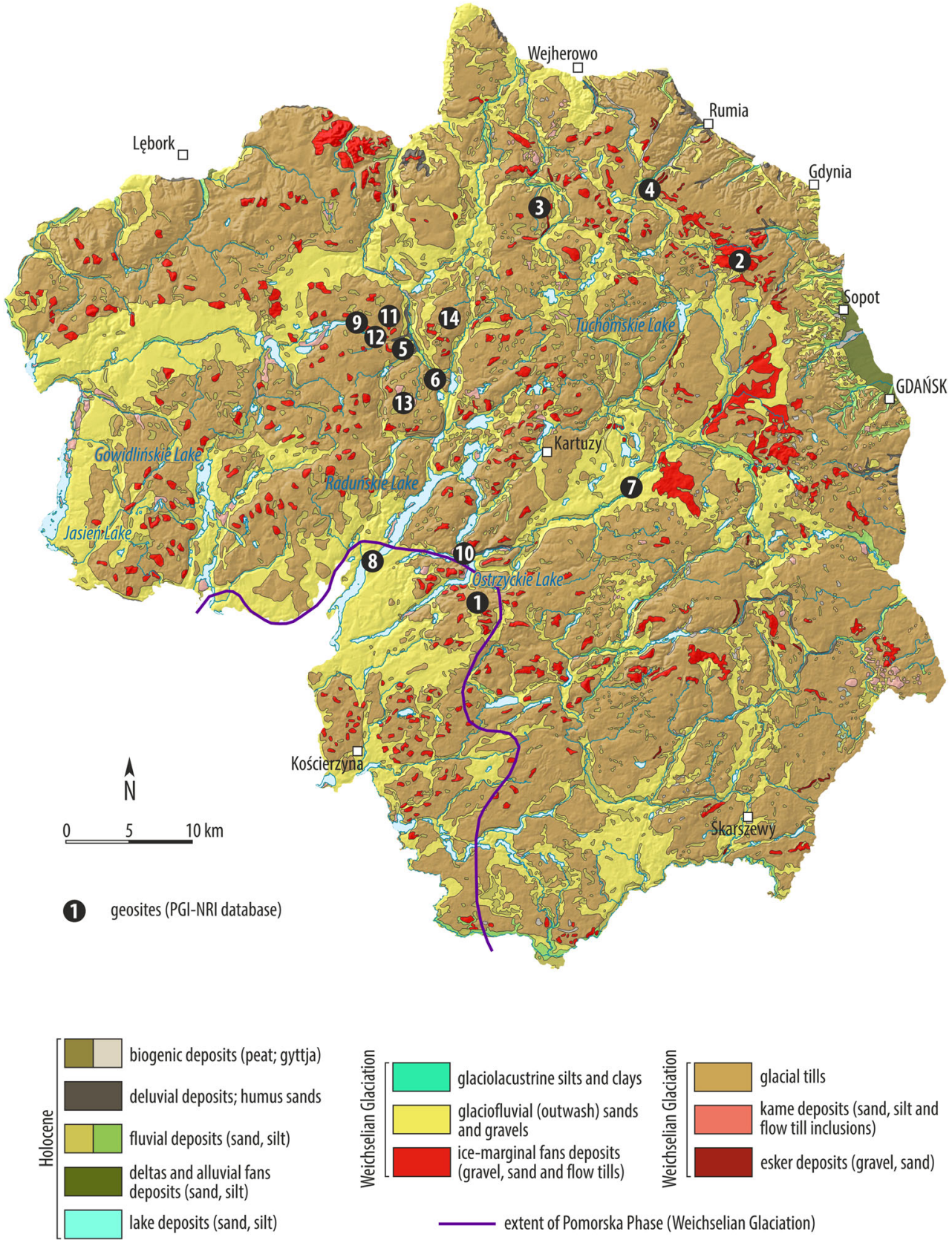

boulders. From this number, the authors have chosen 14 geosites of high scientific and tourist value.

In the area of Górzno, the greatest number of new potential geosites has been indicated by means of both GIS analyses based on the available cartographic materials and field inspection. According to the available database, within the investigated area, there are eight documented geosites. The following study proposes 77 new potential geosites, which, according to the authors, can supplement the existing database.

The geoheritage and potential geosites of the glacial landscapes of northern Poland presented in our study are complementary pieces of information in relation to the other studies describing and evaluating the extent of Pomorska Phase (Weichselian Glaciation)

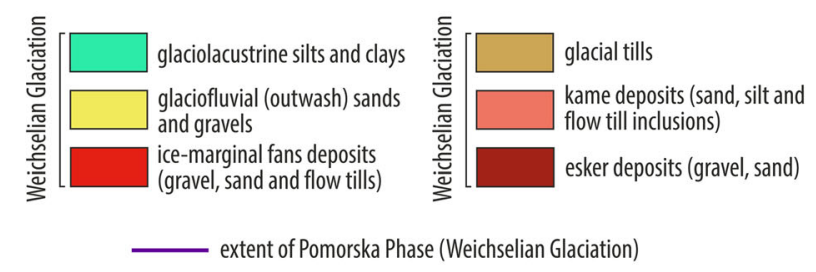

interesting features of glacial landscapes in Poland. For each of the three evaluated regions, attractive geosites have been proposed. This is a database for the construction of geotourist footpaths in the Lower Vistula Valley and in the Kashubian Lake District, and a geopark in the Górzno area in the future. The preparation of the project of the potential Geopark in Górzno area is already underway. The main advantages of the Górzno area being a geopark are the following ones: presence of a wide spectrum of the glacial landforms, the transition from an 'old glacial' landscape (Saalian) to a 'young glacial' landscape (Weichselian), the occurrence of the maximum limit of the last SIS being one of the 
most important geomorphological boundaries in northern Poland and easy access to most of the potential geosites.

The Lower Vistula Valley also seems to show the potential for designing interesting and original geotourist footpaths, mainly because of the occurrence of glacial landforms and sedimentary deposits accessible in the valley escarpment, numerous sites of Pleistocene sandstones and conglomerates, with caves and other karst phenomena, as well as suffosion/ landslides and spring fen niches, the occurrence of interesting fluvial and aeolian landforms.

The area of the Kashubian Lake district is located within the area of ice sheet extent of the Pomorska Phase of the last glaciation, and therefore is characterised by a very fresh glacial landscape. The glacial relief of this area consists of numerous and diversified landforms characterised by high denivelations and concentrations of erratic boulders. Postglacial landform sediments are also very common here (e.g. peatbogs).

The studied areas of young glacial lowland in northern Poland presented above display a high level of geotourist attractiveness. The areas described along with indicated existing and potential geosites show geological and geomorphological heritage from the glacial period in the Earth's history. Welldocumented geosites will enable better understanding of processes and formations that occurred during continental glaciations. It was the authors' intention to emphasize the attractiveness of northern Poland for geotourist purposes.

Open Access This article is licensed under a Creative Commons Attribution 4.0 International License, which permits use, sharing, adaptation, distribution and reproduction in any medium or format, as long as you give appropriate credit to the original author(s) and the source, provide a link to the Creative Commons licence, and indicate if changes were made. The images or other third party material in this article are included in the article's Creative Commons licence, unless indicated otherwise in a credit line to the material. If material is not included in the article's Creative Commons licence and your intended use is not permitted by statutory regulation or exceeds the permitted use, you will need to obtain permission directly from the copyright holder. To view a copy of this licence, visit http://creativecommons.org/licenses/by/4.0/.

\section{References}

Alexandrowicz Z, Poprawa D, Rączkowski W (1998) The regional network of geosites in the Polish Carpathians. Prz Geol 46(8/2):775781

Alexandrowicz Z (2006) Geopark - nature protection category aiding the promotion of geotourism (Polish perspectives). Geoturystyka 2(5): $3-13$

Alexandrowicz Z (2008) Sandstone rocky forms in the Polish Carpathians attractive for education and tourism. Prz Geol 56(8/1): 680-687

Alexandrowicz Z, Alexandrowicz WP, Buczek K (2019) Conservation of the Natura 2000 areas in the context of environmental changes in past and present: a case from the Polish Carpathians. Geoheritage 11:517-529. https://doi.org/10.1007/s12371-018-0302-3

Badura J, Gawlikowska E, Kasiński JR, Koźma J, Kupetz M, Piwocki M, Rascher J (2003) Geopark Łuk Mużakowa-proponowany transgraniczny obszar ochrony georóżnorodności. Prz Geol 51:54 58

Baryła J, Urban J, Zagórski S (1998) Jaskinie Niżu Polskiego. Polskie Towarzystwo Przyjaciół Nauk, Warszawa

Bradbury J (1993) A preliminary geoheritage inventory of the eastern Tasmania Terrane. A report to Park and Wildlife service, Tasmania

Brilha J (2002) Geoconservation and protected area. Environ Conserv 29: 273-276

Brilha J (2016) Inventory and quantitative assessment of geosites and geodiversity sites: a review. Geoheritage 8:119-134. https://doi. org/10.1007/s12371-014-0139-3

Brilha J (2017) Geoheritage and Geoparks. In: Reynard E, Brilha J (eds) Geoheritage: assessment, protection, and management. Elsevier, Amsterdam, pp 323-335

Brocx M, Semeniuk V (2007) Geoheritage and geoconservation-history, definition, scope, and scale. J R Soc West Aust 90:53-80

Brocx M, Semeniuk V (2011) Assessing geoheritage values: a case study using the Leschenault Peninsula and its leeward estuarine lagoon, south-western Australia. Proc Linnean Soc NSW 132:115-130

Bruno DE (2015) Concept of Geosite. In: Tiess G, Majumder T, Cameron $\mathrm{T}$ (eds) Encyclopedia of mineral and energy policy. Springer, Berlin, pp 1-5. https://doi.org/10.1007/978-3-642-40871-7 6-1

Ehlers J, Gibbard PL, Hughes PD (eds) (2011) Quaternary glaciations extent and chronology, a closer look. Developments in quaternary sciences, vol 15. Elsevier, Amsterdam

French H (2007) The periglacial environment. Longman, London

Górska-Zabielska M, Nowicka N, Zawieja J (2015) Georóżnorodność i walory geoturystyczne Drawieńskiego Parku Narodowego, NW Polska. Biul Państw Inst Geol 463:1-42

Graniczny M, Kowalski Z, Czarnogórska M, Krzeczyńska M, Pupienis D, Satkunas J (2008) Projected Geopark Yotvings-PolishLithuanian cross border area. Prz Geol 56(8/1):611-613

Gray M (2004) Geodiversity - valuing and conserving abiotic nature. Wiley, Chichester

Gray M (2005) Geodiversity and geoconservation: what, why, and how? In: Santucci VL (ed) Geodiversity and Feoconservation. The George Wright Forum 22(3):4-12

Herbichowa M (1998) Ekologiczne studium rozwoju torfowisk wysokich właściwych na przykładzie wybranych obiektów z środkowej części Pobrzeża Bałtyckiego. Wydawnictwo Uniwersytetu Gdańskiego, Gdańsk

Karasiewicz MT, Hulisz P, Świtoniak M (2014) Wpływ procesów denudacji na właściwości osadów wypełniających zagłębienia między krętymi wałami z erozji wód subglacjalnych w okolicy Zbójna (Pojezierze Dobrzyńskie). Landform Analy 25:29-42

Kot R (2006) Georóżnorodność - problem jej oceny i zastosowania w ochronie i kształtowaniu środowiska na przykładzie fordońskiego odcinka doliny dolnej Wisły i jej otoczenia. Studia Societatis Scientiarum Torunensis 12(2):1-19

Kot R (2012) Zastosowanie indeksu georóżnorodności dla określenia zróżnicowania rzeźby terenu na przykładzie zlewni reprezentatywnej Strugi Toruńskiej, Pojezierze Chełmińskie. Prob Ekol Kraj 33:87-96

Kotarbiński J (1996) Objaśnienia do Szczegółowej Mapy Geologicznej Polski, sheet 325 - Skrwilno. Polish Geological Institut, Warszawa

Kotarbiński J (1998) Szczegółowa Mapa Geologiczna Polski, sheet 325 Skrwilno. Polish Geological Institut, Warszawa

Kozarski S (1995) Deglacjacja północno-zachodniej Polski: warunki środowiska i transformacja geosystemu $\sim 20 \mathrm{ka} \rightarrow 10 \mathrm{ka} \mathrm{BP}$. Dokumentacja Geograficzna 1. IGiPZ PAN, Warszawa

Kozłowski (1999) Programme of geodiversity conservation in Poland. Pol Geol Inst Sp Papers 2:15-18 
Lesemann J-E, Piotrowski JA, Wysota W (2010) Glacial curvilineations: new glacial landforms produced by longitudinal vortices in subglacial meltwaters flows. Geomorphology 120:153-161

Lesemann J-E, Piotrowski JA, Wysota W (2014) Genesis of the 'glacial curvilineation' landscape by meltwater processes under the former Scandinavian Ice Sheet, Poland. Sediment Geol 312:1-18

Marks L (2012) Timing of the Late Vistulian (Weichselian) glacial phases in Poland. Quat Sci Rev 44:81-88

Marks L, Dzierżek J, Janiszewski R, Kaczorowski J, Lindner L, Majecka A, Makos M, Szymanek M, Tołoczko-Pasek A, Woronko B (2016) Quaternary stratigraphy and palaeogeography of Poland. Acta Geol Pol 66(3):403-427

McBriar M (1995) Foreword. In: (ed) Joyce A report prepared for the Australian Heritage Commission. Standing Committee for the Geological Heritage of the Geological Society of Australia Inc., Sydney

Migoń P, Pijet-Migoń E (2016) Overlooked geomorphological component of volcanic geoheritage - diversity and perspectives for tourism industry, Pogórze Kaczawskie Region, SW Poland. Geoheritage 8(4):333-350

Miśkiewicz K, Stadnik R, Waśkowska-Oliwa A (2008) Geodiversity of the Gościbia Stream valley as a geotouristic attraction of the Flysch Carpathians. In: Słomka T (ed) GEOTOUR 2008: Geotourism and minning heritage, 4th International Conference 26-28 June 2008, Kraków, Poland, AGH University of Science and Technology, Kraków, pp 41-42

Mojski JE (2005) Ziemie polskie w czwartorzędzie. Zarys morfogenezy. Państwowy Instytut Geologiczny, Warszawa

Niewiarowski W, Olszewski A, Wysota W (1995) The role of subglacial features in glacial morphogenesis of the Kujawy-Dobrzyń Subphase area in the southern and eastern part of the Chełmno-Dobrzyń Lakeland. Quatern Stud Pol 13:65-76

Nizicka D, Pochocka-Szwarc K, Ber A (2008) Geotourism in the Suwałki Landscape Park. Prz Geol 56(8/1):614-617

Olszewski A (1976) Macrostructural and macrotextural analysis as a basis of the lithofacial conception of subglacial boulder clays (in the light of the section Morsk I and Morsk II on the lover Vistula). In: Skankowski W (ed) Till - its genesis and diagenesis. Zeszyty Naukowe UAM, Geografia 12:247-251

Panizza M (2001) Geomorphosites: concepts, methods, and example of geomorphological survey. Chin Sci Bull 46:4-6

Petelski K, Moczulska G (2006) Objaśnienia do Szczegółowej Mapy Geologicznej Polski w skali 1:50 000 arkusz Egiertowo. Państwowy Instytut Geologiczny, Warszawa

Pereira P, Pereira D, Caetano Alves MI (2008) Geomorphosite assessment in Montesinho natural park (Portugal). Boletin de la AGE 47: 397-399

Ratajczak-Szczerba M (2011) Charakterystyka geomorfologiczna obszaru położonego wzdłuż Doliny Środkowej Noteci. Landform Analy 16:99-106

Reynard E, Panizza M (2005) Geomorphosites: definition, assessment and mapping. An introduction. Geomorphol 3:177-180

Roszko L (1968) Recesja ostatniego lądolodu skandynawskiego z Polski. In: Galon R (ed) Ostatnie zlodowacenie skandynawskie w Polsce. Prace Geograficzne 74:98-100

Sobiech M (2012) Geneza rzeźby glacjalnej podczas maksymalnego zasięgu lądolodu w rejonie Górzna. Dissertation, Nicolaus Copernicu University, Toruń
Semeniuk V, Semeniuk C (2001) Human impacts on globally to regionally significant geoheritage features of the Swan Coastal Plain and adjoining coastal zone, southwestern Australia. In: Gostin (ed) Gondwana to greenhouse: Australian environmental geoscienceThe Australian Environment Austr J Earth Sci Spec Publ 21:181199

Sobiech M, Wysota W (2014) Geneza rzeźby glacjalnej i dynamika ostatniego lądolodu w rejonie Górzna i Lidzbarka (północnośrodkowa Polska) na podstawie analiz geoprzestrzennych. Landform Analy 25:135-142

Świerkosz K, Koźma J, Reczyńska R, Halama M (2017) Muskau Arch Geopark in Poland (Central Europe) - is it possible to integrate geoconservation and geoeducation into biodiversity conservation? Geoheritage 9:59-69

Tylmann K, Woźniak PP, Rinterknecht V (2018) Erratics selection for cosmogenic nuclide exposure dating-an optimization approach. Baltica 31(2):100-114

Tylmann K, Rinterknecht VR, Woźniak PP, Bourlès D, Schimmelpfennig I, Guillou V, Team ASTER (2019) The local Last Glacial Maximum of the southern Scandinavian Ice Sheet front: cosmogenic nuclide dating of erratics in northern Poland. Quat Sci Rev 219:36-46

Tyszkowski S (2015) Osuwiska jako szczególny element środowiska przyrodniczego Doliny Dolnej Wisły. In: Pająkowski J (ed) Zespół Parków Krajobrazowych Chełmińskiego i Nadwiślańskiego 1. Polskie Wydawnictwo Reklamowe, Toruń, pp 132-137

Urban J (2000) Skałki i jaskinie piaskowcowe na Niżu Polskim. Prz Geol 48(5):409-411

Urban J, Gagol J (2008) Geological heritage of the Świętokrzyskie (Holy Cross) Mountains (Central Poland). Prz Geol 56(8/1):618-628

Urban J (2007) Jaskinie w Dolinie Dolnej Wisły. Jaskinie 2(47):31-32

Urban J (2015) Jaskinie w rejonie Doliny Dolnej Wisły. In: Pająkowski J (ed) Zespół Parków Krajobrazowych Chełmińskiego i Nadwiślańskiego 1. Polskie Wydawnictwa Reklamowe, Toruń, pp 138-144

Weckwerth P (2006) Problem bifurkacji Wisły pod Fordonem (Bydgoszcz) na tle ewolucji Kotliny Toruńskiej pod koniec Plenivistulianu. Prz Geol 78(1):47-68

Weckwerth P (2010) Evolution of the Torun Basin in the Late Weichselian. Landform Analy 14:57-84

Weckwerth P (2018) Fluvial responses to the Weichselian ice sheet advances and retreats: implications for understanding river paleohydrology and pattern changes in Central Poland. Int J Earth Sci 107(4):1407-1429

Wysota W (1992) Morfogeneza środkowo-wschodniej części Pojezierza Chełmińsko-Dobrzyńskiego w świetle badań osadów i form zlodowacenia vistuliańskiego. Wydawnictwo Uniwersytetu M. Kopernika, Toruń

Wysota W, Lankauf KR, Szmańda J, Chruścińska A, Oczkowski HL, Przegiętka KR (2002) Chronology of the Vistulian (Weichselian) glacial events the middle Lower Vistula region, middle-North Poland. Geochronometria 21:137-142

Wysota W, Molewski P, Sokołowski RJ (2009) Record of the Vistula ice lobe advances in the Late Weichselian glacial sequence in northcentral Poland. Quat Int 207:26-41

Zgłobicki W, Baran-Zgłobicka B (2013) Geomorphological heritage as a tourist attraction. A case study of the Lubelskie Province, SE Poland. Geoheritage 5(2):137-149

Zwoliński Z (2010) Aspekty turystyczne georóżnorodności rzeźby Karpat. Prace Komisji Krajobrazu Kulturowego PTG 14:316-327 